\title{
Sleep Deprivation Effects on Circadian Clock Gene Expression in the Cerebral Cortex Parallel Electroencephalographic Differences among Mouse Strains
}

\author{
Jonathan P. Wisor, ${ }^{1}$ Ravi K. Pasumarthi, ${ }^{1}$ Dmitry Gerashchenko, ${ }^{1}$ Carol L. Thompson, ${ }^{2}$ Sayan Pathak, ${ }^{2}$ Aziz Sancar, ${ }^{3}$ \\ Paul Franken, ${ }^{4}$ Ed S. Lein, ${ }^{2}$ and Thomas S. Kilduff ${ }^{1}$ \\ ${ }^{1}$ Biosciences Division, SRI International, Menlo Park, California 94025, ${ }^{2}$ Allen Institute for Brain Science, Seattle, Washington 98103, ${ }^{3}$ Department of \\ Biochemistry and Biophysics, University of North Carolina, Chapel Hill, North Carolina 27599, and ${ }^{4}$ Department of Biological Sciences, Stanford University, \\ Stanford, California 94305
}

\begin{abstract}
Sleep deprivation (SD) results in increased electroencephalographic (EEG) delta power during subsequent non-rapid eye movement sleep (NREMS) and is associated with changes in the expression of circadian clock-related genes in the cerebral cortex. The increase of NREMS delta power as a function of previous wake duration varies among inbred mouse strains. We sought to determine whether SD-dependent changes in circadian clock gene expression parallel this strain difference described previously at the EEG level. The effects of enforced wakefulness of incremental durations of up to $6 \mathrm{~h}$ on the expression of circadian clock genes (bmal1, clock, cry1, cry2, csnk1 $\mathrm{\varepsilon}$, npas2, per1, and per2) were assessed in AKR/J, C57BL/6J, and DBA/2J mice, three strains that exhibit distinct EEG responses to SD. Cortical expression of clock genes subsequent to SD was proportional to the increase in delta power that occurs in inbred strains: the strain that exhibits the most robust EEG response to SD (AKR/J) exhibited dramatic increases in expression of bmall, clock, cry2, csnkIE, and npas2, whereas the strain with the least robust response to SD (DBA/2) exhibited either no change or a decrease in expression of these genes and cry1. The effect of SD on circadian clock gene expression was maintained in mice in which both of the cryptochrome genes were genetically inactivated. $c r y 1$ and $c r y 2$ appear to be redundant in sleep regulation as elimination of either of these genes did not result in a significant deficit in sleep homeostasis. These data demonstrate transcriptional regulatory correlates to previously described strain differences at the EEG level and raise the possibility that genetic differences underlying circadian clock gene expression may drive the EEG differences among these strains.
\end{abstract}

Key words: E-box; delta power; real-time PCR; immediate early genes; mouse strain differences; sleep homeostasis

\section{Introduction}

Sleep deprivation $(\mathrm{SD})$ results in a constellation of changes in gene expression in the brain (Cirelli et al., 2004; Terao et al., 2006; Mackiewicz et al., 2007; Maret et al., 2007). These changes, together with the observation that the electroencephalographic (EEG) consequences of SD are genetically determined in rodents (Franken et al., 1998, 1999; Wisor et al., 2002), are compatible with the hypothesis that sleep need is driven by wake-related changes in the brain concentrations of genetically encoded macromolecules (Wisor and Kilduff, 2005; Cirelli, 2006). Sleep- and wake-related changes in CNS gene expression thus serve as biomarkers for sleep loss and recovery and provide insights into the functional consequences of SD.

Among the transcripts that exhibit sleep-related changes in cerebral cortex $(\mathrm{Cx})$ are the circadian clock genes period1 and

Received Jan. 18, 2008; revised May 7, 2008; accepted May 27, 2008

This work was supported by United States Army Medical Research Acquisition Activity Award W81X-WH-06-10131 and National Institutes of Health Grants HL59658 and MH67752.

Correspondence should be addressed to Dr. Jonathan P. Wisor, Biosciences Division, SRI International, Menlo Park, CA 94025. E-mail: jonathan.wisor@sri.com.

DOI:10.1523/JNEUROSCI.1150-08.2008

Copyright $\odot 2008$ Society for Neuroscience $\quad$ 0270-6474/08/287193-09\$15.00/0 period2 (abbreviated as per 1 and per 2 and referred to collectively as per genes) (Wisor et al., 2002; Franken et al., 2006, 2007). Although the mechanisms underlying the dynamics of sleep history-dependent per gene expression in the $\mathrm{Cx}$ are unclear, some clues are provided by studies on the molecular basis for the circadian regulation of per genes. Mammalian circadian rhythms are regulated by a molecular transcription/translation feedback loop involving transcriptional inhibitory proteins (PER1, PER2, CRY1, and CRY2) and transcriptional activating proteins (BMAL1/MOP3, CLOCK, and NPAS2), the kinetics of which are influenced by the activity of casein kinase I $\varepsilon$ (for review, see Ueda et al., 2005; Herzog, 2007; Liu et al., 2007). In the forebrain, the per and cry genes are targets for regulation by the CLOCK paralog NPAS2 acting in concert with BMAL1 (Reick et al., 2001). Given the role of NPAS2 in regulating gene expression changes in association with cellular metabolic state (Rutter et al., 2001), this transcriptional network may function as a mediator of neurochemical changes in the $\mathrm{Cx}$ in accordance with cerebral metabolic state and sleep need, a concept supported by EEG studies on cry1,2 null mutant mice (Wisor et al., 2002).

In the current study, we assessed the effects of SD on the expression of circadian clock genes in the $\mathrm{Cx}$. Comparisons were 
made among three strains of mice, AKR/J (AK), C57BL/6J (B6), and DBA/2J (D2), known to differ in their response to SD (Franken et al., 2001). Although the amplitude of EEG oscillations in the delta $(1-4 \mathrm{~Hz})$ range during non-rapid eye movement sleep (NREMS) increases in proportion to previous wakefulness in all three strains, the rate at which this increase occurs is greatest in $\mathrm{AK}$, intermediate in $\mathrm{B} 6$, and least in $\mathrm{D} 2$ mice. Because the molecular underpinnings of these strain differences are not known, we hypothesized that these strain differences at the EEG level are related to differences in circadian clock gene expression in the $\mathrm{Cx}$. We also used cry 1,2 single and double knock-out mice to assess the effects of disruption of the circadian feedback loop on SD responses at the molecular and EEG levels. Our results demonstrate that genetic differences in sleep EEG are related to circadian clock gene expression in the $\mathrm{Cx}$.

\section{Materials and Methods}

Animals. Male mice of the AK, B6, and D2 strains were purchased from The Jackson Laboratory. $c r y 1^{-1-}$ and $c r y 2^{-1-}$ mice originated at the University of North Carolina, where they were backcrossed to congenic status in a B6 background. These lines were maintained at Stanford University by inbreeding. The origin and breeding of cry $1,2^{-/-}$mice has been described previously (Selby et al., 2000; Wisor et al., 2002). Mice were maintained in an $12 \mathrm{~h}$ light/dark cycle (LD) with ad libitum food and water before experimentation. All experimental procedures complied with institutional animal care and use committee regulations and National Institutes of Health guidelines for the care and use of experimental animals.

Sleep studies. Male mice aged 8-10 weeks were anesthetized and surgically prepared with a cranial implant for EEG and electromyogram (EMG) recording. Frontal ( $1.5 \mathrm{~mm}$ lateral from midline, $1.5 \mathrm{~mm}$ anterior from bregma) and parietal ( $1.5 \mathrm{~mm}$ lateral from midline, $5 \mathrm{~mm}$ posterior from bregma) leads were used for EEG recording, and bilateral EMG leads placed $2-3 \mathrm{~mm}$ from the midline in the neck musculature were used for EMG recording. Mice were placed in the recording environment with ad libitum food and water no sooner than $14 \mathrm{~d}$ after surgery. Recording cables were attached to the cranial implants at least $48 \mathrm{~h}$ before initiation of recordings. In the SD experiments described below, wakefulness was maintained by visual inspection of the animals, sensory stimulation, and introduction of novel objects into the cages. Each SD session was preceded by a $24 \mathrm{~h}$ baseline session during which mice were undisturbed.

EEG data collection and analysis. For studies of AK, B6, and D2 strains, EEG (digitization rate, $100 \mathrm{~Hz}$ ) and EMG (digitization rate, $200 \mathrm{~Hz}$ ) were collected via the Embla 16-channel A10 hardware system and digitized with the Somnologica Science software application. Methods for studies of $c r y 1^{-1-}$ and $c r y 2^{-1-}$ mice were as described for cry $1,2^{-1-}$ mice (Wisor et al., 2002). Digitized EEG (bandpass, 1-30 Hz; digitization rate, 100 $\mathrm{Hz}$ ), integrated EMG (bandpass, $10-100 \mathrm{~Hz}$ ), wheel running, and drink signal (binary variables) were stored in 10 s epochs. EEG data were bandpass filtered $(1-30 \mathrm{~Hz})$ and EMG data were high-pass filtered $(>10 \mathrm{~Hz})$ for ease of visualization. Epochs were processed in $10 \mathrm{~s}$ intervals and classified as wake, rapid eye movement sleep (REMS) or NREMS by individuals expert in rodent sleep-state classification. EEG data were fast Fourier transformed in $10 \mathrm{~s}$ epochs. The average delta power $(0.5-4 \mathrm{~Hz})$ was summated for each NREMS epoch and averaged over all NREMS epochs. Brief awakenings were defined as wake episodes comprising fewer than three consecutive wake epochs. The numbers of these brief awakenings and the average NREMS delta power were tallied during the time interval over which 360 epochs (i.e., 1 cumulative hour) of sleep accumulated after each SD session.

Assessment of gene expression by real-time PCR. Methods for quantitative real-time PCR (qPCR) have been described previously (Terao et al., 2003a, 2004, 2006). Briefly, after cervical dislocation, the Cx was removed from the skull, frozen on dry ice, and stored at $-80^{\circ} \mathrm{C}$ until RNA extraction. Total RNA was isolated from the $\mathrm{Cx}$ of each mouse using the RNeasy mini kit (Qiagen). To avoid any genomic DNA contamination, total RNA was treated with RNase-free DNase 1 (Qiagen). First-strand
Table 1. Primer and probe sequences used for quantitative real-time PCR analyses

\begin{tabular}{|c|c|c|}
\hline $\begin{array}{l}\text { Gene } \\
\text { name }\end{array}$ & Amplicon (bp) & Primer/probe sequence \\
\hline bmal1 & 65 & $\begin{array}{l}\text { F: GAACAGCTATCTTCCTCGGACACT } \\
\text { R: GGAAGTCCAGTCTTGGCATCA } \\
\text { P: 6FAM5' -CGCCCCGGGAGCGACTCA-3'TAMRA }\end{array}$ \\
\hline clock & 66 & $\begin{array}{l}\text { F: CCACATGCCTCCCACTTTTC } \\
\text { R: TGCGGATGAGGCTGGACTA } \\
\text { P: 6FAM5'-ATTCCCTCCCCTTCTGCCGTAGCC-3'TAMRA }\end{array}$ \\
\hline cry1 & 73 & $\begin{array}{l}\text { F: TGGCCAAATGGGCAGAAG } \\
\text { R: CCCTCCTGACGAAGCTGAGT } \\
\text { P: 6FAM5'-TTCCCGTGGATTGACGCCATCA-3'TAMRA }\end{array}$ \\
\hline cry2 & 63 & $\begin{array}{l}\text { F: CGAAGCCCTGGCCAAGT } \\
\text { R: GTCATGATGGCGTCAATCCA } \\
\text { P: 6FAM5'-CCGAGGGCAAGACAGGCTTCCC-3' TAMRA }\end{array}$ \\
\hline $\operatorname{csnk} 1 \epsilon$ & 66 & $\begin{array}{l}\text { F: TTCGACTGGAACATGCTCAAAT } \\
\text { R: CCGTCTTTCCCGGTCTACATC } \\
\text { P: 6FAM5' -CGGTGCAGCCCGGAATCCC-3'TAMRA }\end{array}$ \\
\hline npas2 & 95 & $\begin{array}{l}\text { F: ATGTGTGTAGCTGACGAACCTTTAGA } \\
\text { R: ATGATTGGAGGAGCTCTGTGATC } \\
\text { P: 6FAM5'-TCACTTCGAGGCATAGCTTGGAATGGA-3'TAMRA }\end{array}$ \\
\hline per1 & 67 & $\begin{array}{l}\text { F: CAGCTGGGCCGGTTTTG } \\
\text { R: CACTTTATGGCGACCCAACA } \\
\text { P: 6FAM5'-CACCCCTGGAGCCGCAAGGTG-3'TAMRA }\end{array}$ \\
\hline per2 & 98 & $\begin{array}{l}\text { F: GTCCACCTCCCTGCAGACAA } \\
\text { R: TCATTAGCCTTCACCTGCTTCAC } \\
\text { P: 6FAM5' -CTGGCAACCTTGAAGTATGCCCTGC-3'TAMRA }\end{array}$ \\
\hline g3pdh & 65 & $\begin{array}{l}\text { F: CAACGGGAAGCCCATCAC } \\
\text { R: CGGCCTCACCCCATTTG } \\
\text { P: } 6 \text { VIC5'-ATCTTCCAGGAGCGAGACCCCACTAACA-3' TAMRA }\end{array}$ \\
\hline
\end{tabular}

$F$, Forward primer; $R$, reverse primer; $P$, TaqMan probe.

cDNA was prepared from the Cx RNA using a high-capacity cDNA reverse transcription kit (Applied Biosystems). For each real-time PCR reaction, the target cDNA of interest along with reference cDNA [glyceraldehyde-3-phosphate dehydrogenase ( $g 3 p d h)$ ] were simultaneously amplified in 96-well plates using the Applied Biosystems 7500 Real Time PCR System. Eight different concentrations of mouse Cx cDNA standards were also amplified in the same plate. Standards were prepared by serial dilution of a cDNA pool composed of equal amounts of cDNA from all experimental samples on the plate. All reactions were performed in triplicate. Relative expression levels were thus determined for bmal1, clock, cry 1, cry2, csnk1 1 , npas2, per1, and per2. The primer and probe sequences chosen from the coding regions of the genes of interest were determined using Primer Express version 1.0 software (Applied Biosystems); sequences used are listed in Table 1. To confirm the specificity of the nucleotide sequences chosen for the primers and probes and the absence of DNA polymorphisms, BLASTN searches were conducted against the dbEST and nonredundant set of GenBank, EMBL (European Molecular Biology Laboratory), and DDBJ (DNA Data Bank of Japan) databases (Terao et al., 2003b).

Assessment of gene expression by in situ hybridization and subsequent analyses. Digoxigenin-based in situ hybridization (ISH) was performed on brains of male B6 mice subjected to $6 \mathrm{~h}$ SD ending at Zeitgeber time 6 (ZT6) (SD group; $n=3$ ) or killed as time-of-day controls (SDC group; $n=3$ ). Expression of the immediate early gene (IEG) junB and per 1 was analyzed by colorimetric ISH using a standard protocol (Lein et al., 2007). For the junB and perl probe sequences used, see http://www. brain-map.org/pdf/NeuroBlast.pdf. For a given gene and condition, a set of ISH images spanning a sagittal hemisphere (image series) were generated by an automated platform (Lein et al., 2007). Using an automated informatics data processing pipeline ( $\mathrm{Ng}$ et al., 2007), each ISH image series was mapped onto the three-dimensional (3-D) Allen Reference Atlas (Dong, 2008), and informatics parameters such as expression level (measure of ISH signal intensity), density (measure of expression area), and energy (a measure combining level and density into a single measurement) were calculated (Lein et al., 2007). For each image series, the expression energy measured at each voxel was normalized by subtracting 
the mean expression energy across all the voxels in the image series. In this study, the averaged expression profile for a given gene and condition was generated using the normalized image series from three biological replicates, preserving anatomical information about expression. "Heat maps" of induced gene expression were generated by aligning ISH data to a 3-D framework, segmenting expression as an intensity-related measurement calculated per $100 \mu \mathrm{m}^{2}$ voxel, normalizing and averaging the three replicate ISH files for each condition, calculating the difference in expression between the indicated conditions, and viewing the output as a heat map superimposed on a Nissl atlas. Thus, the "difference heat map" illustrated in Figure 3 was computed by subtracting the average expression energy between the $\mathrm{SD}$ condition and its control for a given gene.

Experiment 1: effects of SD on circadian clock-related gene expression in the cortex of $A K, B 6, D 2$, and cry1,2 $2^{-1-}$ mice. For qPCR studies, AK, B6, and D2 mice instrumented for EEG and EMG recordings were subjected to single SD sessions lasting 0 (time-of-day control), 2, 4, or $6 \mathrm{~h}$ ending at ZT6 ( $n=8$ mice per strain per SD duration) and were killed by cervical dislocation at the end of SD. For in situ hybridization studies, B6 mice were subjected to a single SD session lasting 0 (time-of-day control) or $6 \mathrm{~h}$ ending at ZT6 ( $n=3$ mice per group) and were killed by cervical dislocation at the end of SD. $c r y 1,2^{-/-}$mice ( $n=8$ mice per SD duration) were subjected to single SD sessions lasting 0 (time-of-day control) or $6 \mathrm{~h}$ ending at ZT6 and were killed by cervical dislocation at the end of SD. Because all mice were killed at the same time of day, any difference between the control and SD groups is a reflection of sleep history rather than time of day.

Experiment 2: sleep phenotypes of $\mathrm{cryl}^{-1-}$ and $\mathrm{cry}^{-1-}$ mice under baseline and SD conditions. The baseline distribution of sleep and wakefulness under $12 \mathrm{~h} \mathrm{LD}$ conditions was recorded across the $24 \mathrm{~h}$ period for $\mathrm{cryl}^{-1-}$ and $\mathrm{cry} 2^{-/-}$mice relative to the $\mathrm{B} 6$ strain. To evaluate the homeostatic response to sleep loss in these strains, $c r y 1^{-/-}$and $c r y 2^{-/-}$ mice were subjected to a series of SD sessions separated by intervals of at least $5 \mathrm{~d}$ in the following order: $1 \mathrm{~h} \mathrm{SD}$ ending at ZT6, $6 \mathrm{~h}$ SD ending at ZT6, $3 \mathrm{~h}$ SD ending at ZT6, $6 \mathrm{~h}$ SD ending at ZT12, and $6 \mathrm{~h}$ SD ending at ZT0. The $6 \mathrm{~h}$ SD ending at ZT0 was performed in dim red light ( $<10$ lux), whereas all other SD sessions were performed in white light. The number of brief awakenings and NREMS delta power were assessed during the first hour of sleep occurring after cessation of SD.

Experiment 3: determination of circadian period in $\mathrm{cryl}^{-1-}$ and cry $2^{-1-}$ mice. On the day subsequent to the last SD session, recording cables were detached from the $c r y 1^{-1-}$ and $c r y 2^{-1-}$ mice, and the mice were housed in constant dark for at least $7 \mathrm{~d}$ for measurement of wheelrunning rhythms. For each mouse, the circadian period of locomotor activity was determined by measuring the slope of a regression line that was visually fitted to the onset of wheel running for at least 7 consecutive days of constant dark.

Statistics. Data were analyzed using Statview 5.0.1 software (SAS Institute). For qPCR assays (experiment 1), averages were initially calculated from the triplicates for each individual animal, and then outliers (values that were $>3$ SDs from the mean of the strain-duration group from which they were derived) were eliminated from analysis. In experiments involving SD ( $\mathrm{qPCR}$ assays of the $\mathrm{AK}, \mathrm{B} 6$, and $\mathrm{D} 2$ strains in experiment 1 and EEG studies of $c r y 1^{-/-}$and $c r y 2^{-/-}$mice in experiment 2), the effects of strain, duration of $\mathrm{SD}$, and strain $\times \mathrm{SD}$ duration interaction were assessed by ANOVA. When ANOVA indicated statistically significant effects, Dunnett's multiple comparison procedure was used for planned post hoc comparisons of SD groups to the control group (" $0 \mathrm{~h}$ SD") within each strain. For qPCR assays of the cry $1,2^{-1-}$ strain in experiment 1 , the effect of SD on gene expression was assessed by Student's $t$ test for unpaired samples. In baseline sleep EEG (experiment 2) and wheel-running assays (experiment 3 ) of $c r y 1^{-/-}$and $c r y 2^{-1-}$ and B6 control mice, significant effects of strain and time of day as well as interactions among these factors were assessed by ANOVA. Dunnett's multiple comparison procedure was then used for planned post hoc comparisons of $c r y 1^{-/-}$and $c r y 2^{-/-}$with B6 control mice.

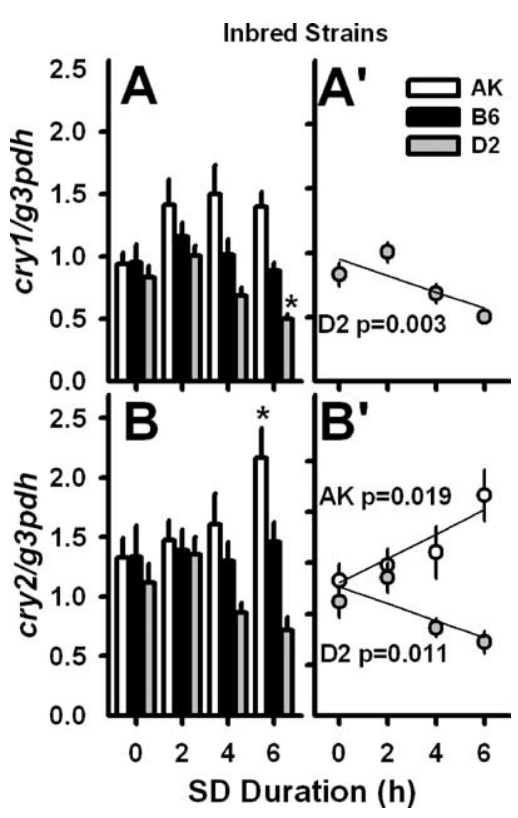

Figure 1. $\boldsymbol{A}, \boldsymbol{B}$, Effect of sleep deprivation on $\operatorname{cry} 1(\boldsymbol{A})$ and $\mathrm{cry} 2(\boldsymbol{B})$ expression in the $(\mathrm{x}$ of $A \mathrm{~K}$, B6, and D2 mice. Mice were killed at ZT6 after being subjected to 2, 4, or $6 \mathrm{~h}$ of SD, or as time-of-day controls (labeled 0). *Significantly different from time-of-day controls, Dunnett's test. $\boldsymbol{A}^{\prime}, \boldsymbol{B}^{\prime}$, Gene expression data (symbols), regression lines, and $p$ values from strains in which regression analysis indicated statistically significant relationships between SD duration and gene expression.

\section{Results}

\section{Experiment 1: effects of SD on circadian clock-related gene} expression in the cortex of $\mathrm{AK}, \mathrm{B} 6, \mathrm{D} 2$, and $\operatorname{cry} 1,2^{-/-}$mice The amount of wakefulness during SD was not affected by genotype; mice of all genotypes spent $\sim 90 \%$ of time awake across SD sessions.

\section{Expression of circadian transcriptional inhibitors: cry1, cry2,} per1, and per2

In the $\mathrm{Cx}$ of the $\mathrm{AK}, \mathrm{B} 6$, and D2 strains, cry1 expression was significantly affected by SD duration $\left(F_{(3,70)}=3.16 ; p=0.030\right)$ (Fig. 1A); however, the changes were strain specific: cry 1 expression decreased significantly with SD in the D2 strain. cry 1 expression in the $\mathrm{Cx}$ was also significantly modified as a function of strain $\left(F_{(2,70)}=18.38 ; p<0.001\right)$; this effect reflects the fact that there was a significant inverse relationship between SD duration and cry 1 expression in D2 mice $\left(p=0.003\right.$ ) (Fig. $\left.1 A^{\prime}\right)$ but not in the other two strains. Baseline cry 1 values were not significantly different among strains.

cry2 expression in the $\mathrm{Cx}$ was not significantly affected by SD alone $(p=0.461)$, but there was a significant strain $\times$ SD duration interaction $\left(F_{(6,70)}=2.71 ; p=0.020\right)$ (Fig. $\left.1 B\right)$. cry2 was elevated by SD in AK mice (significantly so at $6 \mathrm{~h}$ ). A significant effect of strain on $c r y 2$ expression $\left(F_{(2,70)}=11.38 ; p<0.001\right)$ was a consequence of SD-dependent changes: although baseline $c r y 2$ values did not significantly differ among strains, regression analysis revealed a significant direct relationship between SD duration and cry 2 expression in AK mice $(p=0.019)$ and an inverse relationship between SD duration and cry2 expression in D2 mice $(p=0.011)$ (Fig. $\left.1 B^{\prime}\right)$.

per1 expression in the $\mathrm{Cx}$ was significantly affected by SD duration $\left(F_{(3,65)}=10.84 ; p<0.001\right)$ (Fig. $\left.2 A\right)$, with immediate elevation of per 1 relative to baseline after $2 \mathrm{~h} \mathrm{SD}$ across all three strains (Dunnett's test). Strain also influenced per1 expression $\left(F_{(2,65)}=6.35 ; p=0.003\right)$; this effect was a consequence of SD- 


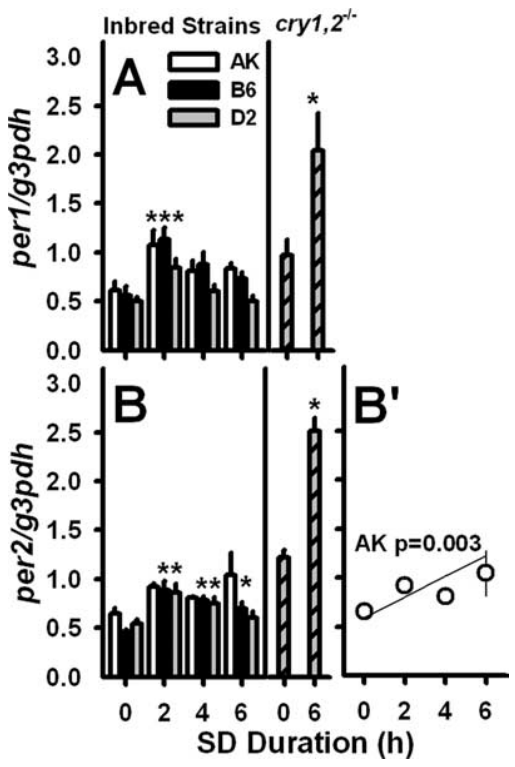

Figure 2. $\quad \boldsymbol{A}, \boldsymbol{B}$, Effect of sleep deprivation on per1 $(\boldsymbol{A})$ and per2 $(\boldsymbol{B})$ expression in the $\mathrm{C}$ of $\mathrm{AK}$, B6, D2, and cry1,2 ${ }^{-/-}$mice. Mice were killed at ZT6 after being subjected to 2, 4, or $6 \mathrm{~h}$ of SD, or as time-of-day controls (labeled 0 ). *Significantly different from time-of-day controls, Dunnett's test. $\boldsymbol{B}^{\prime}$, Gene expression data (symbols), regression line, and $p$ value from the AK strain, in which regression analysis indicated a statistically significant relationship between SD duration and gene expression.

dependent changes as baseline per1 values were not significantly different among strains. The finding that per1 elevation was limited to the $2 \mathrm{~h}$ SD group was unanticipated, because previous assays of perl expression in forebrain showed significant elevation at $6 \mathrm{~h}$ (Franken et al., 2007). This discrepancy might be a consequence of subcortical changes in perl expression. Indeed, as indicated by colorimetric whole-brain in situ hybridization, per 1 expression at $6 \mathrm{~h}$ SD was elevated in the striatum, olfactory bulb, and the superficial layers of the $\mathrm{Cx}$ relative to time-of-day controls (Fig. $3 A, C, E$ ). The anatomical localization of per 1 induction during SD overlapped considerably with that of junB (Fig. $3 B, D, F)$.

Like that of per1, cortical per2 expression was significantly affected by SD duration $\left(F_{(3,72)}=9.38 ; p<0.001\right)$ (Fig. $2 B$ ), with significant elevation of per 2 relative to baseline beginning at $2 \mathrm{~h}$ $\mathrm{SD}$ in B6 and D2 mice (Dunnett's test without respect to strain). Strain also influenced per 2 expression $\left(F_{(2,72)}=5.07 ; p=0.009\right)$; baseline per 2 values were significantly greater in AK than in B6 by $\sim 40 \%$, whereas per 2 expression in D2 mice was intermediate and not significantly different from the other two strains. Regression analysis indicated a significant direct relationship between SD duration and per 2 expression in AK mice $(p=0.003)$ (Fig. $\left.2 B^{\prime}\right)$.

After $6 \mathrm{~h}$ of SD, per1 and per2 expression were elevated in cry $1,2^{-1-}$ mice relative to time-of-day controls of the same genotype (Student's $t$ test, $p<0.05$ ) (Fig. $2 A, B$ ). Expression of both genes under baseline conditions was approximately equivalent to that of the inbred AK, B6, and D2 strains at their highest levels, i.e., after SD. Furthermore, the effect of SD on per gene expression was greater in magnitude in $c r y 1,2^{-/-}$mice than in any of the three inbred strains: per1 and per 2 mRNA levels were elevated more than twofold relative to time-of-day controls in $\mathrm{cry} 1,2^{-/-}$ mice. Collectively, these results demonstrate that the effect of SD on per gene expression is not only intact but potentiated in cry $1,2^{-/-}$mice relative to inbred strains.
Expression of circadian transcriptional activators: bmal1, clock, and npas2

Bmall expression in the Cx was significantly affected by SD duration $\left(F_{(3,71)}=3.62 ; p=0.017\right)$ (Fig. $4 A$ ) and was changed relative to baseline only after $6 \mathrm{~h} \mathrm{SD}$ (Dunnett's test without respect to strain). Strain significantly affected bmall expression $\left(F_{(2,71)}=7.54 ; p=0.001\right)$ because of strain-specific (AK and B6) elevation of bmal1 during SD. Although baseline bmal1 values were not significantly different among strains, regression analysis indicated a significant direct relationship between SD duration and bmal1 expression in AK mice $(p=0.011)$ (Fig. $\left.4 A^{\prime}\right)$ and $\mathrm{B} 6$ mice $(p=0.022)$ (Fig. $\left.4 A^{\prime}\right)$.

Cortical clock expression was significantly modified as a function of SD duration $\left(F_{(3,71)}=8.53 ; p<0.001\right)$ (Fig. $\left.4 B\right)$, strain $\left(F_{(2,71)}=32.41 ; p<0.001\right)$, and strain $\times$ SD duration interaction $\left(F_{(6,71)}=6.39 ; p<0.001\right)$ : at the $6 \mathrm{~h}$ time point, clock expression was more than double baseline levels in AK, modestly elevated in B6 mice, and reduced below baseline levels in D2 mice. Regression analysis indicated a significant direct relationship between SD duration and clock expression in AK mice $(p=0.001)$ and B6 mice ( $p=0.004)$, in contrast to a significant inverse relationship in $\mathrm{D} 2$ mice $(p=0.036)$ (Fig. $\left.4 B^{\prime}\right)$.

npas 2 was significantly influenced by $\operatorname{SD}\left(F_{(3,72)}=4.96 ; p=\right.$ 0.004 ) (Fig. 4C) and was elevated relative to baseline only after $6 \mathrm{~h}$ $\mathrm{SD}$ (Dunnett's test without respect to strain). npas2 expression was also influenced by strain $\left(F_{(2,72)}=11.02 ; p<0.001\right)$ but did not differ among strains in baseline conditions; a strain $\times$ SD duration interaction was nearly statistically significant ( $p=$ 0.053). Although npas 2 expression remained stable throughout $\mathrm{SD}$ in $\mathrm{D} 2$ mice, regression analysis indicated significant direct relationships between $\mathrm{SD}$ duration and npas 2 expression in $\mathrm{AK}$ $(p=0.001)$ and B6 $(p=0.025)$ mice (Fig. $\left.4 C^{\prime}\right)$.

The effect of SD on the expression of circadian transcriptional activators in $\mathrm{cry} 1,2^{-/-}$mice did not parallel that of any one inbred strain. After $6 \mathrm{~h}$ of SD, bmall expression was elevated by SD in $\operatorname{cry} 1,2^{-1-}$ mice relative to time-of-day controls (Student's $t$ test, $p<0.05$ ) (Fig. $4 A$ ) to a level that was similar to that of AK mice. In contrast, expression of both clock and npas 2 was significantly suppressed relative to time-of-day controls of the same genotype (Student's $t$ test, $p<0.05$ ) (Fig. $4 B, C$ ), a pattern resembling that of D2 mice.

Expression of a regulator of clock kinetics: csnkIs csnkI $\varepsilon$ expression was not significantly affected by SD but differed by strain $\left(F_{(2,71)}=3.68 ; p=0.030\right)$, and the response to $\mathrm{SD}$ also differed by strain $\left(F_{(6,71)}=3.01 ; p=0.011\right)$ (Fig. $5 A)$. Although csnkIع expression remained stable throughout $\mathrm{SD}$ in B6, D2, and cry 1,2 $2^{-/}$mice, expression of csnkIE was significantly elevated above baseline levels in AK mice after $6 \mathrm{~h}$ of SD. Regression analysis confirmed the direct relationship between $\mathrm{SD}$ duration and $\operatorname{csnk} 1 \varepsilon$ expression in $\mathrm{AK}$ mice $(p=$ 0.001) (Fig. 5 $A^{\prime}$ )

Experiment 2: sleep phenotypes of $c r y 1^{-/-}$and $c r y 2^{-/-}$mice under baseline and SD conditions

Baseline sleep measures in cry $1^{-1-}$ and $\mathrm{cry} 2^{-1-}$ mice

cry $1,2^{-/-}$mice exhibit hypersomnolence as evidenced by elevated NREMS delta power and sleep time relative to wild-type control mice (Wisor et al., 2002). As shown in Figure 2, these mice exhibit elevated cerebral cortical per gene expression under both baseline and SD conditions. We sought to determine whether one or the other cry genes was responsible for the sleep phenotype in the double knock-out. The fact that cry 1 and cry 2 

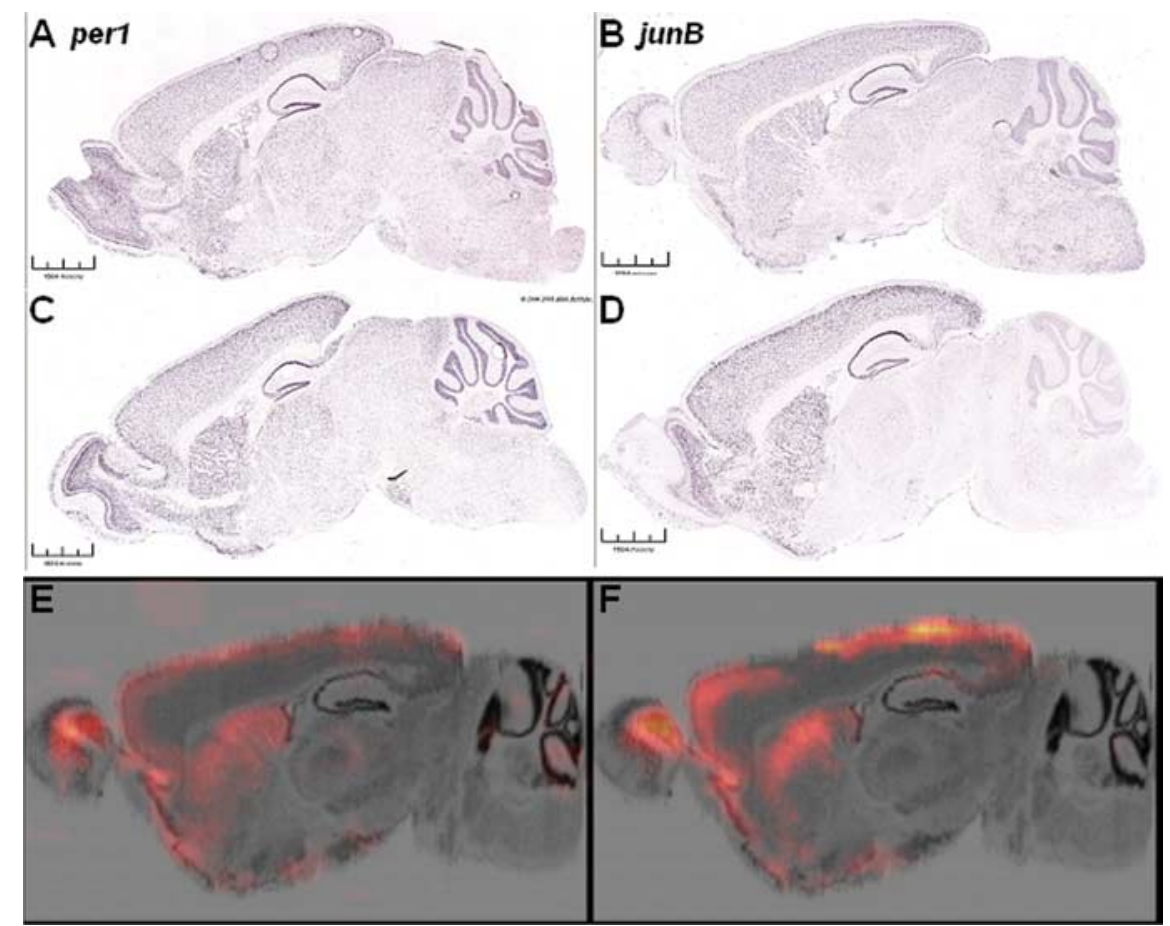

Figure 3. $A-\boldsymbol{F}$, Colorimetric in situ hybridization analysis of per $1(\boldsymbol{A}, \boldsymbol{C}, \boldsymbol{E})$ and jun $B(\boldsymbol{B}, \boldsymbol{D}, \boldsymbol{F})$ expression in $B 6$ brain. Sagittal sections are shown from time-of-day control $(\boldsymbol{A}, \boldsymbol{B})$ and $6 \mathrm{hSD}(\boldsymbol{C}, \boldsymbol{D})$ mice. $\boldsymbol{E}, \boldsymbol{F}$, Heat maps indicate differences in the mean in situ hybridization signals between the $S D(n=3)$ and $\operatorname{SDC}(n=3)$ groups, with saturation being proportional to the magnitude of increased signal in SD relative to SDC brains.

expression profiles are nearly identical during enforced wake (Fig. 1) led us to hypothesize that the two cry genes are functionally redundant in sleep regulation and that neither of these proteins alone is necessary for normal sleep regulation. Accordingly, we assessed the sleep/wake patterns of $c r y 1^{-/-}$and $c r y 2^{-/-}$mice relative to $\mathrm{B} 6$ mice in baseline conditions and after $\mathrm{SD}$. Comparison of $c r y 1^{-1-}$ and $c r y 2^{-1-}$ mice to wild-type controls under baseline conditions in a $12 \mathrm{~h} \mathrm{LD}$ regimen indicated significant time-of-day effects on NREMS $\left(F_{(7,175)}=19.08 ; p<0.001\right)$, $\operatorname{REMS}\left(F_{(7,175)}=4.98 ; p<0.001\right)$, and wake $\left(F_{(7,175)}=20.44 ; p<\right.$ 0.001 ) percentages (Fig. 6). Although genotype had no main effect on NREMS, REMS, or wake times $(p>0.25)$, genotype $\times$ time interactions were significant for NREMS $\left(F_{(14,175)}=3.51\right.$; $p<0.001)$, REMS $\left(F_{(14,175)}=2.01 ; p=0.019\right)$, and wake $\left(F_{(14,175)}\right.$ $=4.17 ; p<0.001)$ percentages, indicating a different distribution of these states across the $24 \mathrm{~h}$ period. $c r y 1^{-1-}$ mice exhibited progressively more wake (Fig. $6 A$ ), and less REMS (Fig. $6 C$ ), and NREMS (Fig. $6 E$ ) as a percentage of time relative to wild-type mice through the mid to late portion of the light phase (i.e., $3 \mathrm{~h}$ intervals ending at ZT9 and ZT12), whereas daytime sleep in cry $2^{-/-}$mice was not different from that of wild-type mice in any $3 \mathrm{~h}$ interval. Both $\mathrm{cry} 1^{-/-}$and $c r y 2^{-/-}$mice had significantly more wake (Fig. $6 A, B$ ) and less NREMS (Fig. $6 E, F$ ) than wildtype controls in the mid portion of the dark phase, when B6 mice exhibit a "siesta-like" increase in sleep as a percentage of time. Like NREMS percentage, NREMS delta power varied significantly with time of day $\left(F_{(7,175)}=3.54 ; p=0.001\right)$ but was not significantly affected by genotype $(p>0.25)$. There was a significant genotype $\times$ time-of-day interaction $\left(F_{(14,175)}=2.50 ; p=\right.$ 0.003 ) such that NREMS delta power was lower in $\mathrm{cry} 2^{-/-}$mice (Fig. $6 \mathrm{H}$ ) but not $\mathrm{cryl}^{-1-}$ mice (Fig. $6 \mathrm{G}$ ) than in wild-type mice in the mid portion of the dark phase (i.e., $3 \mathrm{~h}$ intervals ending at ZT18 and ZT21).
Effects of increasing durations of enforced wakefulness on subsequent sleep in cry $^{-1-}$ and cry $2^{-1-}$ mice

When wild-type $\mathrm{B} 6, \mathrm{cry}^{-/-}$, and $c r y 2^{-1-}$ mice were kept awake for 1,3 , and $6 \mathrm{~h}$ intervals ending at ZT6, the number of brief awakenings during the first hour of subsequent sleep decreased $\left(F_{(3,75)}=6.14 ; p<\right.$ 0.001) (Fig. 7A) and NREMS delta power increased $\left(F_{(3,75)}=51.93 ; p<0.001\right)$ (Fig. $7 B$ ) in a manner that was dependent on SD duration. The effects of SD on NREMS delta power and number of brief awakenings did not differ by genotype (genotype main effect, $p>0.50$; genotype $\times$ duration interaction, $p>0.09$ ), suggesting an intact sleep homeostatic response in these null mutant mice.

Time-of-day modulation of the response to enforced wakefulness in $\mathrm{cryl}^{-1-}$ and cry $2^{-1-}$ mice

When wild-type $\mathrm{B} 6, \mathrm{cryl}^{-/[\text {minus }]}$ and $\mathrm{cry}^{-/-}$mice were kept awake by gentle stimulation for $6 \mathrm{~h}$ intervals ending at ZT0, ZT6, and ZT12, the number of brief awakenings decreased (Fig. 8A) $\left(F_{(1,48)}=7.81\right.$; $p=0.010)$ and NREMS delta power increased (Fig. $8 B)\left(F_{(1,48)}=88.45 ; p<\right.$ $0.001)$ during the first accumulated hour of sleep after cessation of SD relative to baseline conditions. Time of day had a significant effect on delta power $\left(F_{(2,48)}=19.79 ; p<0.001\right)$, with values from both SD and baseline days declining from ZT0 through ZT12 but not the number of brief awakenings ( $p>0.1$ ). Genotype had neither a main effect nor significant interactions with either SD or time of day in modulating delta power or the number of brief awakenings, further indicating an intact sleep homeostatic response in these knock-out mice.

\section{Experiment 3: determination of circadian period in $c r y 1^{-/-}$ and $\operatorname{cry} 2^{-/-}$mice}

The circadian wheel-running phenotype of $c r y 1^{-/-}$and $c r y 2^{-/-}$ mice (van der Horst et al., 1999) was verified by housing these mice in constant darkness for 1 week. Mice housed in constant darkness over a $7 \mathrm{~d}$ interval subsequent to EEG/EMG recordings exhibited genotype-dependent differences $(p<0.001)$ in the circadian period of wheel-running rhythms (Fig. 9). The average duration of circadian cycles (i.e., circadian period) was shortest in cry $1^{-/-}$mice $(22.8 \pm 0.1 \mathrm{~h})$, intermediate in B6 mice (23.7 \pm $0.1 \mathrm{~h})$, and longest in $c r y 2^{-/-}$mice $(24.1 \pm 0.1 \mathrm{~h})$.

\section{Discussion}

NREMS delta power, a quantitative measure of the amplitude and prevalence of EEG slow waves (1-4 Hz), tracks sleep need over time (Franken et al., 1991; Borbely and Achermann, 2004). Strain differences in the temporal dynamics of NREMS delta power demonstrate that there are genetically encoded differences in sleep need; the magnitude of the increase in NREMS delta power as a result of $\mathrm{SD}$ is much greater in the AK strain than in the D2 strain (Franken et al., 2001). We reasoned that, if these strain differences in sleep need are genetically encoded, then they might be apparent in gene expression profiles as well. The current study focused on a transcriptional regulatory network centering on the 


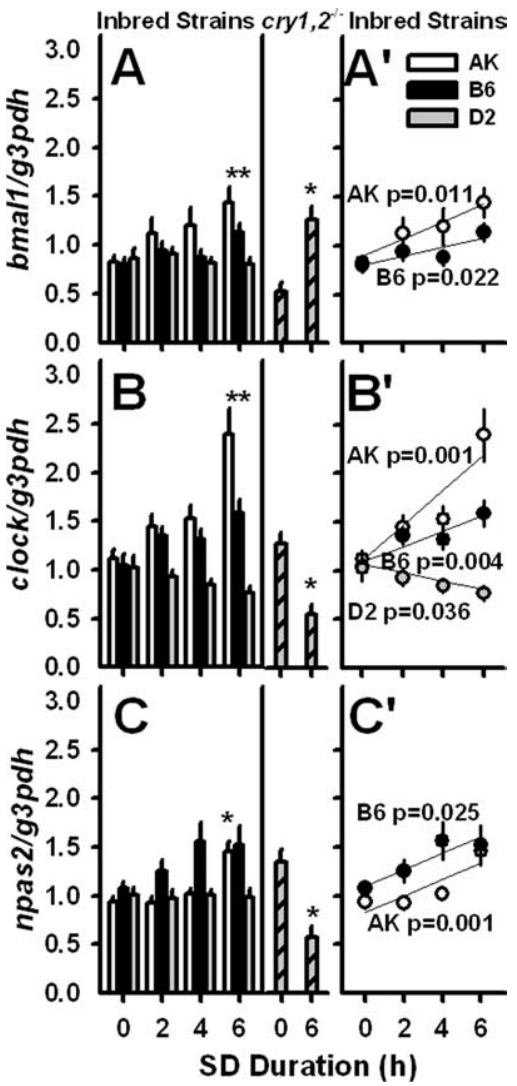

Figure 4. $\quad \boldsymbol{A}, \boldsymbol{B}, \boldsymbol{C}$, Effect of sleep deprivation on bmal7 $(\boldsymbol{A}), \operatorname{clock}(\boldsymbol{B})$, and npas2 ( $\boldsymbol{C}$ ) expression in the $C x$ of $A K, B 6, D 2$, and $c r y 1,2^{-1-}$ mice. Mice were killed at $Z T 6$ after being subjected to 2 , 4 , or $6 \mathrm{~h}$ of SD or as time-of-day controls (labeled 0 ). ${ }^{*}$ Significantly different from time-of-day controls, Dunnett's test. $\boldsymbol{A}^{\prime}, \boldsymbol{B}^{\prime}, \boldsymbol{C}^{\prime}$, Gene expression data (symbols), regression lines, and $p$ values from strains in which regression analysis indicated statistically significant relationships between SD duration and gene expression.

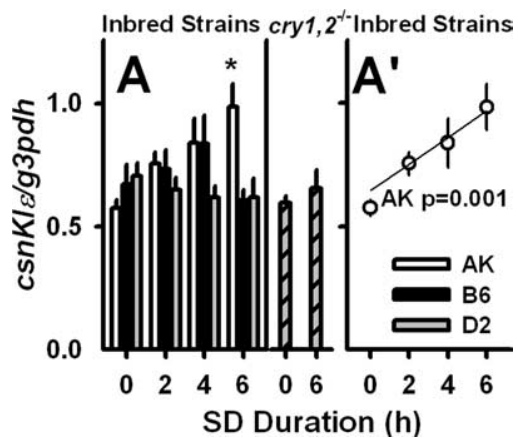

Figure 5. Effect of sleep deprivation on csnk1 $\varepsilon$ expression in the $C x$ of $A K, B 6, D 2$, and cry $1,2^{-1-}$ mice. Mice were killed at ZT6 after being subjected to 2,4, or $6 \mathrm{~h}$ of SD or as timeof-day controls (labeled 0). *Significantly different from time-of-day controls, Dunnett's test. $\boldsymbol{A}^{\prime}$, Gene expression data (symbols), regression line, and $p$ value from the AK strain, in which regression analysis indicated a statistically significant relationship between SD duration and gene expression.

E-box DNA element that has been linked to sleep need by studies of mutant mice (Naylor et al., 2000; Wisor et al., 2002; Dudley et al., 2003; Laposky et al., 2005; Franken et al., 2006). Our data show that the positive regulators of E-box transcriptional activity associated with the circadian clock, bmal1, clock, and npas2, are uniformly upregulated in the AK strain but are unaffected by SD in the D2 strain. This observation leads to the possibility that E-box-mediated gene expression may be a driver of sleep need.
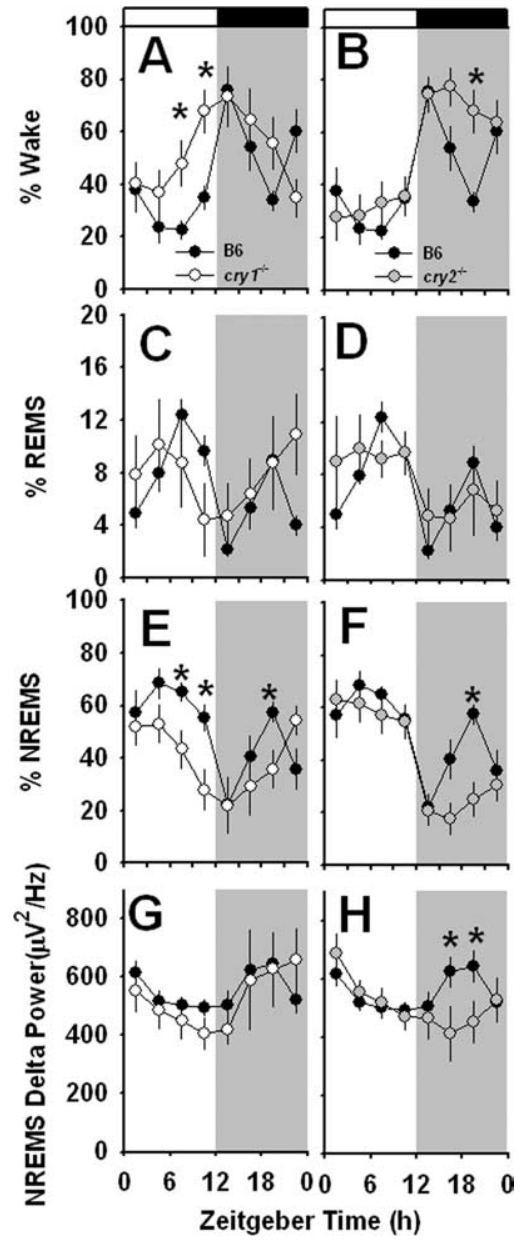

Figure 6. $\quad A-H$, Daily profiles of sleep and wake states and NREMS delta power in $c r y 1^{-/-}$ (gray bars in $\boldsymbol{A}, \boldsymbol{C}, \boldsymbol{E}, \boldsymbol{G}$ ) and $c r y 2^{-1-}$ (gray bars in $\boldsymbol{B}, \boldsymbol{D}, \boldsymbol{F}, \boldsymbol{H}$ ) mice compared with wild-type controls (black bars) under $12 \mathrm{~h} \mathrm{LD}$ conditions with lights off at ZT12. Wake $(\boldsymbol{A}, \boldsymbol{B}), \operatorname{REMS}(\boldsymbol{C}, \boldsymbol{D})$, and NREMS $(\boldsymbol{E}, \boldsymbol{F})$ as a percentage of time and NREMS delta power $(\boldsymbol{G}, \boldsymbol{H})$ were averaged in $3 \mathrm{~h}$ intervals bracketed by the times indicated. * Significantly different from wild-type controls, Dunnett's test.

That this regulatory loop has functional consequences at the EEG level is demonstrated by hypersomnolence in cry 1,2 double knock-out mice (Wisor et al., 2002, although not in single knockouts, as we show here) and reduced sleep in npas 2 knock-out (Dudley et al., 2003; Franken et al., 2006) and clock mutant (Naylor et al., 2000) mice. Together, these data implicate some of the molecular components of the core loop of the circadian clock in the electroencephalographic expression, if not the generation, of sleep need.

The current report adds to a substantial body of literature on the effects of SD on gene expression (Cirelli and Tononi, 2004; Cirelli, 2005; Terao et al., 2006; Conti et al., 2007; Mackiewicz et al., 2007) and expands on previous reports that demonstrated changes in the expression of genes associated with circadian clock function. As shown previously (Wisor et al., 2002; Franken et al., 2007), expression levels of per 1 and per 2 in the brains of rodents are upregulated as a consequence of enforced waking. The delayed effects of SD on other circadian clock-related genes that influence E-box-mediated transcription are a novel observation. E-box-mediated transcriptional regulation influences the expression of thousands of transcripts (Zheng et al., 2001; Grundschober et al., 2001; Akhtar et al., 2002; Duffield et al., 2002; Panda et al., 2002; Oishi et al., 2003), although in the Cx many of 


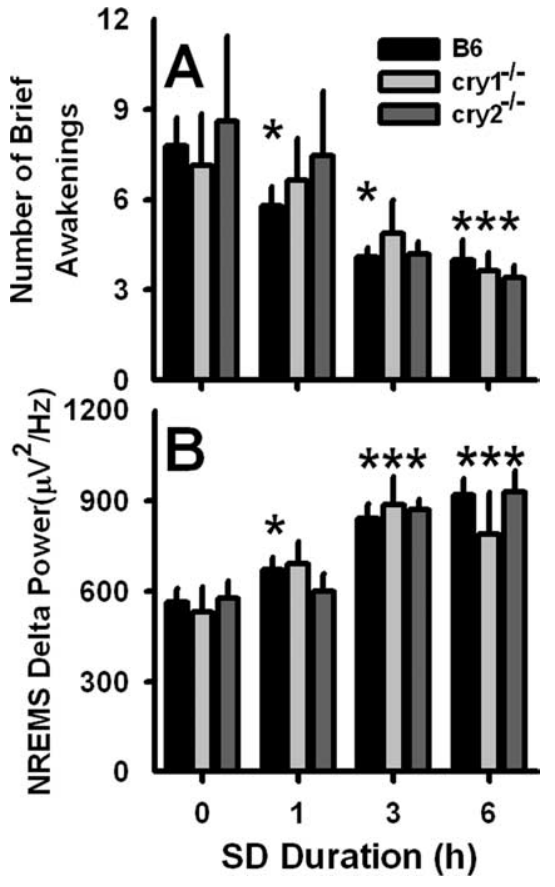

Figure 7. Effects of SD of three different durations on sleep parameters during the first hour of subsequently accumulated sleep in wild-type (black bars), $c r y 1^{-/-}$(light gray bars), and cry $2^{-\prime-}$ (dark gray bars) mice. $\boldsymbol{A}$, Number of brief awakenings. $\boldsymbol{B}$, NREMS delta power. *Significantly different from time-of-day controls, Dunnett's test.

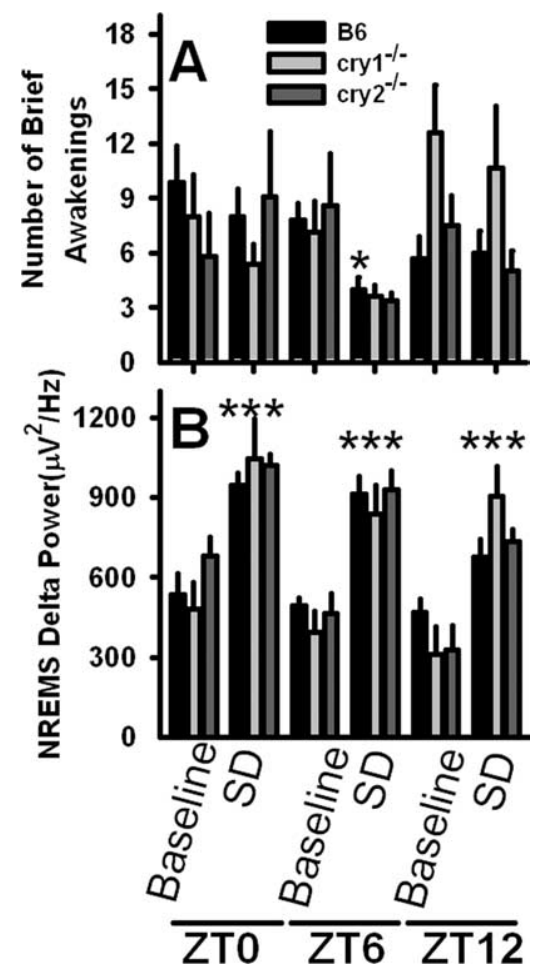

Figure 8. Time-of-day effects of $6 \mathrm{~h} \mathrm{SD}$ on sleep parameters in $c r y 1^{-/-}, \mathrm{cry} 2^{-/-}$, and wild-type control mice. $A$, Number of brief awakenings. $\boldsymbol{B}$, NREMS delta power. *Significantly different from baseline, Dunnett's test. Data for SD ending at ZT6 are the same as those presented in Figure 7.

those transcripts change secondarily to sleep and wake (Maret et al., 2007). Numerous changes in gene expression are thus likely to occur during SD as a consequence of E-box-mediated transcription. Similarly, disruption of cry expression has numerous con-

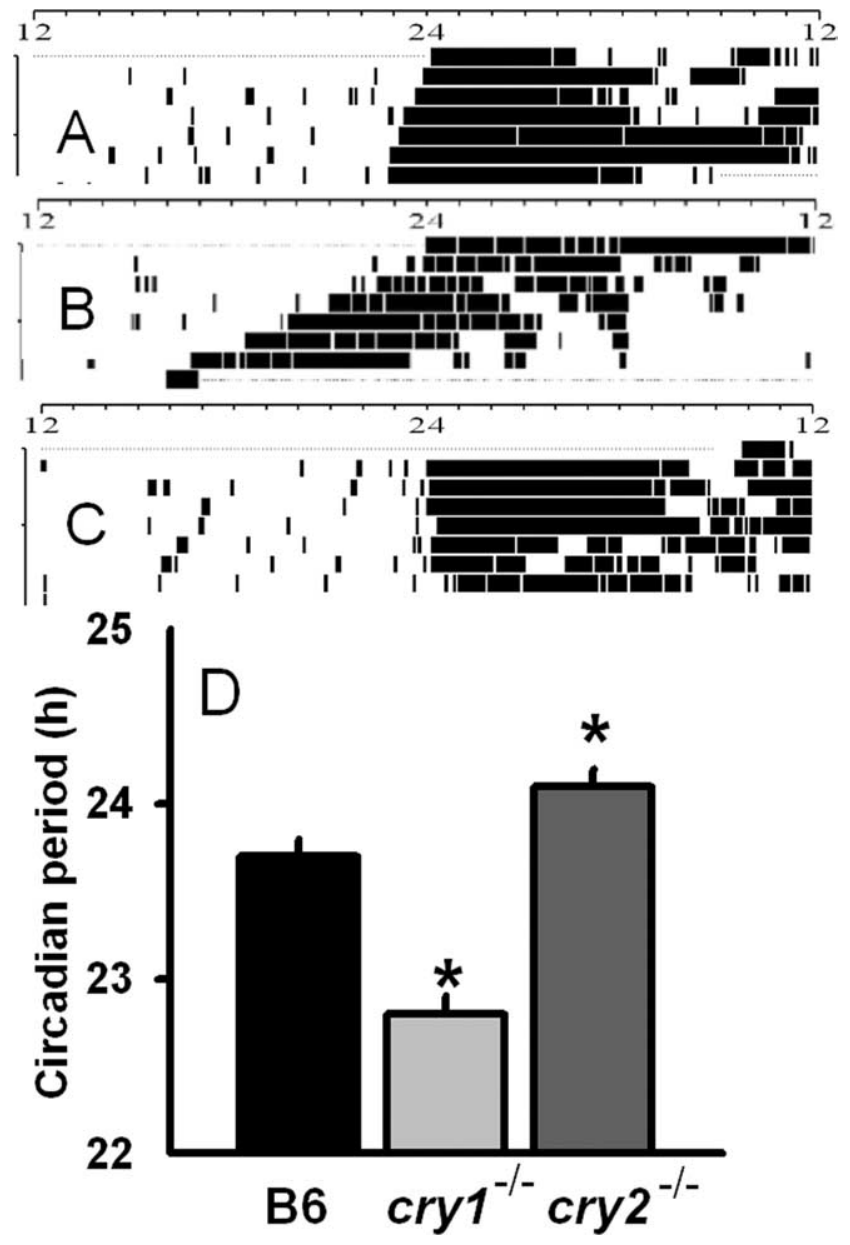

Figure 9. $A-C$, Representative actograms of circadian wheel-running rhythms of $B 6(A)$, cry $1^{-\prime-}(\boldsymbol{B})$, and cry $2^{-\prime-}(\boldsymbol{C})$ mice housed in constant darkness for $7 \mathrm{~d}$. $\boldsymbol{D}$, Circadian period was significantly affected by genotype $(p<0.001)$. *Significantly different from wild-type controls, Dunnett's test.

sequences at the level of gene transcription (Oishi et al., 2003), and, consequently, the sleep phenotype of $c r y 1,2^{-/-}$mice cannot be attributed to any specific target of CRY-mediated transcriptional regulation. Nor can this sleep phenotype be attributed to either cry1 or cry2 specifically, because neither $\mathrm{cryl}^{-/-}$nor cry $2^{-\prime-}$ mice exhibited the sleep phenotype of the double knockout under baseline or post-SD conditions in the current study (Figs. 6-8).

Molecular and EEG sleep phenotypes of cryptochrome-deficient animals

To determine the degree to which SD-induced changes are dependent on functional CRY proteins, we assessed the effects of SD on per 1 and per 2 expression in $c r y 1 / 2^{-/-}$mice. Induction of both per 1 and per 2 by SD was potentiated in these mice (Fig. 2). The induction of per mRNA in response to cellular activation such as serum stimulation of fibroblasts (Yagita et al., 2001) or light stimulation of per expression in the suprachiasmatic nucleus ( $\mathrm{SCN}$ ) (Vitaterna et al., 1999) occurs in cryptochrome-deficient mice and is driven by a calcium/cyclic AMP response element (CRE) in the per gene promoters (Travnickova-Bendova et al., 2002; Gamble et al., 2007). This IEG-like response nonetheless appears to be modulated by E-box-mediated transcriptional regulation, as demonstrated by the potentiated induction of perl and per 2 during SD in $c r y 1 / 2^{-/-}$mice. This potentiation might be attributable 
to the loss of negative feedback of PER and CRY on per transcription. CRY proteins are necessary for circadian gating of c-fos induction by light in the SCN (Thompson et al., 2004). The induction of per genes in the Cx by SD, even as an immediate early response, may be subjected to similar gating mechanisms. Additional support for the influence of E-box-mediated transcriptional regulation on the response to $\mathrm{SD}$ is provided by the fact that per induction during SD is attenuated in mice genetically deficient in npas2 (Franken et al., 2006).

The observation of elevated per gene expression in the cry $1,2^{-/-}$mice is conceptually straightforward. In contrast, the effects of cry 1,2 knock-out on the positive regulators of E-box transcription do not conform with any mechanistic model of gene regulation. Although these positive regulators generally cycle in synchrony, they may nonetheless be influenced by independent regulatory mechanisms. In this context, it is interesting to note that the transcript encoding $d b p$, which, like per and $c r y$ genes, is known to be regulated by an E-box, is downregulated in the brain by SD (Wisor et al., 2002; Cirelli et al., 2004; Franken et al., 2007), whereas the other E-box-regulated circadian transcripts, including per 1, per2, cry 1 , and cry2, are upregulated (albeit in a strain-dependent manner). Thus, a unitary response of functionally related transcriptional activators to SD, even within a strain, should not be expected. In addition, there is the possibility of pleiotropy with a knock-out animal; perhaps a signaling pathway that regulates npas 2 but does not regulate bmal1, for instance, is disrupted in $c r y 1,2^{-/-}$mice.

\section{SD induces a familiar cascade of circadian clock gene expression}

The neurochemical changes that occur in association with SD (most consistently in AK mice) have several similarities to those elicited acutely by serum stimulation of peripherally derived fibroblast cells and immortalized cell lines. In both serum-exposed fibroblasts (Balsalobre et al., 1998; Yagita et al., 2001) and, as shown in this report, the sleep-deprived Cx,per gene expression is rapidly elevated as an immediate early response (Fig. 2). cryl, cry2, and bmal1, clock, and npas 2 expression are elevated more gradually over several hours after serum exposure in fibroblasts (Balsalobre et al., 1998; Yagita et al., 2001) as well as in the Cx of SD animals (Figs. 1, 4). In addition, knock-out of both cry1 and cry 2 does not prevent per induction from occurring in either the fibroblast model (Yagita et al., 2001) or, as shown in the current report, in the sleep deprived Cx (Fig. 2). Expression of the circadian clock output gene $d b p$ is acutely suppressed in fibroblasts by serum stimulation (Balsalobre et al., 1998; Yagita et al., 2001) and in the brain during SD (Wisor et al., 2002; Cirelli et al., 2004; Franken et al., 2007). Given these parallels in gene expression, the in vitro fibroblast model may provide clues to the mechanisms that underlie circadian clock gene expression in the sleepdeprived Cx. For instance, tumor necrosis factor $\alpha$ (TNF $\alpha$ ) suppresses $d b p$ expression in fibroblasts (Cavadini et al., 2007). Elevated TNF $\alpha$ levels in the brain during SD (Krueger et al., 1998) may thus be responsible for SD-induced suppression of $d b p$ expression. In fibroblasts, per expression is upregulated by several intracellular signaling mechanisms that activate CRE-mediated transcription, including PKA activators and increased intracellular calcium concentration (Balsalobre et al., 2000). In the Cx, CRE-mediated signaling pathways are more active during wake than sleep, as evidenced by the observation that cAMP response element-binding protein phosphorylation, a marker for transcriptional activation via the CRE, is wake dependent and is driven by the locus ceruleus (Cirelli and Tononi, 2000). It is unlikely that the strain differences at the molecular or EEG levels are attributable to a strain difference in the stress response to SD because adrenalectomy, which eliminates circulating corticosterone, does not abolish the differential EEG response to SD in D2 and B6 mice (P. Franken, unpublished observation).

Because $n p a s 2^{-/-}$(Dudley et al., 2003), per $2^{-/-}$(Feillet et al., 2006a), and $c r y 1 / 2^{-/-}$(Iijima et al., 2005) mice are deficient in food anticipatory activity under restricted feeding, it has been proposed that basic helix-loop-helix (bHLH)/PAS-mediated transcription provides a molecular basis for the food-entrainable oscillator (Feillet et al., 2006b). The signaling mechanism by which this oscillator is activated is not known, but it is clear from the current study that enforced wakefulness sets in motion a sequence of events in the bHLH/PAS pathway that bears the hallmarks of an induced circadian oscillation in the cultured fibroblast system. This cascade of events may not establish SCNindependent rhythms of wake and sleep in response to a single SD session attributable to the dominance of the SCN in the timing of wake and sleep. However, the obligation to maintain wakefulness on a daily basis at a time of day when it is not facilitated by the SCN rhythm (as is the case with restricted feeding of nocturnal rodents during the light phase) might induce circadian oscillations independently of the SCN in the $\mathrm{Cx}$, in the dorsomedial hypothalamus (Gooley et al., 2006; Mieda et al., 2006), or in a distributed network of oscillators (Landry et al., 2006).

\section{References}

Akhtar RA, Reddy AB, Maywood ES, Clayton JD, King VM, Smith AG, Gant TW, Hastings MH, Kyriacou CP (2002) Circadian cycling of the mouse liver transcriptome, as revealed by cDNA microarray, is driven by the suprachiasmatic nucleus. Curr Biol 12:540-550.

Balsalobre A, Damiola F, Schibler U (1998) A serum shock induces circadian gene expression in mammalian tissue culture cells. Cell 93:929-937.

Balsalobre A, Marcacci L, Schibler U (2000) Multiple signaling pathways elicit circadian gene expression in cultured Rat-1 fibroblasts. Curr Biol 10:1291-1294.

Borbely AA, Achermann P (2004) Sleep homeostasis and models of sleep regulation. In: Principles and practice of sleep medicine, Ed 3 (Kryger MH, Roth T, Dement WC, eds), pp 377-390. Philadelphia: Saunders.

Cavadini G, Petrzilka S, Kohler P, Jud C, Tobler I, Birchler T, Fontana A (2007) TNF-alpha suppresses the expression of clock genes by interfering with E-box-mediated transcription. Proc Natl Acad Sci USA 104:12843-12848.

Cirelli C (2005) A molecular window on sleep: changes in gene expression between sleep and wakefulness. Neuroscientist 11:63-74.

Cirelli C (2006) Cellular consequences of sleep deprivation in the brain. Sleep Med Rev 10:307-321.

Cirelli C, Tononi G (2000) Differential expression of plasticity-related genes in waking and sleep and their regulation by the noradrenergic system. J Neurosci 20:9187-9194.

Cirelli C, Tononi G (2004) Locus ceruleus control of state-dependent gene expression. J Neurosci 24:5410-5419.

Cirelli C, Gutierrez CM, Tononi G (2004) Extensive and divergent effects of sleep and wakefulness on brain gene expression. Neuron 41:35-43.

Conti B, Maier R, Barr AM, Morale MC, Lu X, Sanna PP, Bilbe G, Hoyer D, Bartfai T (2007) Region-specific transcriptional changes following the three antidepressant treatments electro convulsive therapy, sleep deprivation and fluoxetine. Mol Psychiatry 12:167-189.

Dong HW (2008) Allen reference atlas: a digital color brain atlas of C57BL/6 male mouse. Hoboken, NJ: Wiley.

Dudley CA, Erbel-Sieler C, Estill SJ, Reick M, Franken P, Pitts S, McKnight SL (2003) Altered patterns of sleep and behavioral adaptability in NPAS2deficient mice. Science 301:379-383.

Duffield GE, Best JD, Meurers BH, Bittner A, Loros JJ, Dunlap JC (2002) Circadian programs of transcriptional activation, signaling, and protein turnover revealed by microarray analysis of mammalian cells. Curr Biol 12:551-557.

Feillet CA, Ripperger JA, Magnone MC, Dulloo A, Albrecht U, Challet E 
(2006a) Lack of food anticipation in Per2 mutant mice. Curr Biol 16:2016-2022.

Feillet CA, Albrecht U, Challet E (2006b) "Feeding time" for the brain: a matter of clocks. J Physiol Paris 100:252-260.

Franken P, Tobler I, Borbély AA (1991) Sleep homeostasis in the rat: simulation of the time course of EEG slow-wave activity. Neurosci Lett 130:141-144.

Franken P, Malafosse A, Tafti M (1998) Genetic variation in EEG activity during sleep in inbred mice. Am J Physiol 44:R1127-R1137.

Franken P, Malafosse A, Tafti M (1999) Genetic determinants of sleep regulation in inbred mice. Sleep 22:155-169.

Franken P, Chollet D, Tafti M (2001) The homeostatic regulation of sleep need is under genetic control. J Neurosci 21:2610-2621.

Franken P, Dudley CA, Estill SJ, Barakat M, Thomason R, O'Hara BF, McKnight SL (2006) NPAS2 as a transcriptional regulator of non-rapid eye movement sleep: genotype and sex interactions. Proc Natl Acad Sci U S A 103:7118-7123.

Franken P, Thomason R, Heller HC, O'Hara BF (2007) A non-circadian role for clock-genes in sleep homeostasis: a strain comparison. BMC Neurosci 8:87.

Gamble KL, Allen GC, Zhou T, McMahon DG (2007) Gastrin-releasing peptide mediates light-like resetting of the suprachiasmatic nucleus circadian pacemaker through cAMP response element-binding protein and Per1 activation. J Neurosci 27:12078-12087.

Gooley JJ, Schomer A, Saper CB (2006) The dorsomedial hypothalamic nucleus is critical for the expression of food-entrainable circadian rhythms. Nat Neurosci 9:398-407.

Grundschober C, Delaunay F, Pühlhofer A, Triqueneaux G, Laudet V, Bartfai T, Nef P (2001) Circadian regulation of diverse gene products revealed by mRNA expression profiling of synchronized fibroblasts. J Biol Chem 276:46751-46758.

Herzog ED (2007) Neurons and networks in daily rhythms. Nat Rev Neurosci 8:790-802.

Iijima M, Yamaguchi S, van der Horst GT, Bonnefont X, Okamura H, Shibata S (2005) Altered food-anticipatory activity rhythm in Cryptochromedeficient mice. Neurosci Res 52:166-173.

Krueger JM, Fang J, Taishi P, Chen Z, Kushikata T, Gardi J (1998) Sleep. A physiologic role for IL-1 beta and TNF-alpha. Ann N Y Acad Sci 856:148-159.

Landry GJ, Simon MM, Webb IC, Mistlberger RE (2006) Persistence of a behavioral food-anticipatory circadian rhythm following dorsomedial hypothalamic ablation in rats. Am J Physiol Regul Integr Comp Physiol 290:R1527-R1534.

Laposky A, Easton A, Dugovic C, Walisser J, Bradfield C, Turek F (2005) Deletion of the mammalian circadian clock gene BMAL1/Mop3 alters baseline sleep architecture and the response to sleep deprivation. Sleep 28:395-409.

Lein ES, Hawrylycz MJ, Ao N, Ayres M, Bensinger A, Bernard A, Boe AF, Boguski MS, Brockway KS, Byrnes EJ, Chen L, Chen L, Chen TM, Chin MC, Chong J, Crook BE, Czaplinska A, Dang CN, Datta S, Dee NR, et al. (2007) Genome-wide atlas of gene expression in the adult mouse brain. Nature 445:168-176.

Liu AC, Lewis WG, Kay SA (2007) Mammalian circadian signaling networks and therapeutic targets. Nat Chem Biol 3:630-639.

Mackiewicz M, Shockley KR, Romer MA, Galante RJ, Zimmerman JE, Naidoo N, Baldwin DA, Jensen ST, Churchill GA, Pack AI (2007) Macromolecule biosynthesis-a key function of sleep. Physiol Genomics 31:441-457.

Maret S, Dorsaz S, Gurcel L, Pradervand S, Petit B, Pfister C, Hagenbuchle O, O'Hara BF, Franken P, Tafti M (2007) Homerla is a core brain molecular correlate of sleep loss. Proc Natl Acad Sci U S A 104:20090-20095.

Mieda M, Williams SC, Richardson JA, Tanaka K, Yanagisawa M (2006) The dorsomedial hypothalamic nucleus as a putative food-entrainable circadian pacemaker. Proc Natl Acad Sci U S A 103:12150-12155.

Naylor E, Bergmann BM, Krauski K, Zee PC, Takahashi JS, Vitaterna MH, Turek FW (2000) The circadian clock mutation alters sleep homeostasis in the mouse. J Neurosci 20:8138-8143.
Ng L, Pathak SD, Kuan C, Lau C, Dong H, Sodt A, Dang C, Avants B, Yushkevich P, Gee JC, Haynor D, Lein E, Jones A, Hawrylycz M (2007) Neuroinformatics for genome-wide $3 \mathrm{D}$ gene expression mapping in the mouse brain. IEEE/ACM Trans Comput Biol Bioinform 4:382-393.

Oishi K, Miyazaki K, Kadota K, Kikuno R, Nagase T, Atsumi G, Ohkura N, Azama T, Mesaki M, Yukimasa S, Kobayashi H, Iitaka C, Umehara T, Horikoshi M, Kudo T, Shimizu Y, Yano M, Monden M, Machida K, Matsuda J, et al. (2003) Genome-wide expression analysis of mouse liver reveals CLOCK-regulated circadian output genes. J Biol Chem 278:41519-41527.

Panda S, Antoch MP, Miller BH, Su AI, Schook AB, Straume M, Schultz PG, Kay SA, Takahashi JS, Hogenesch JB (2002) Coordinated transcription of key pathways in the mouse by the circadian clock. Cell 109:307-320.

Reick M, Garcia JA, Dudley C, McKnight SL (2001) NPAS2: an analog of clock operative in the mammalian forebrain. Science 293:506-509.

Rutter J, Reick M, Wu LC, McKnight SL (2001) Regulation of clock and NPAS2 DNA binding by the redox state of NAD cofactors. Science 293:510-514.

Selby C, Thompson C, Schmitz T, Van Gelder R, Sancar A (2000) Functional redundancy of cryptochrome and classical photoreceptors for nonvisual ocular photoreception in mice. Proc Natl Acad Sci U SA 97:14697-14702.

Terao A, Steininger TL, Hyder K, Apte-Deshpande A, Ding J, Rishipathak D, Davis RW, Heller HC, Kilduff TS (2003a) Differential increase in the expression of heat shock protein family members during sleep deprivation and during sleep. Neuroscience 116:187-200.

Terao A, Greco MA, Davis RW, Heller HC, Kilduff TS (2003b) Regionspecific changes in immediate early gene expression in response to sleep deprivation and recovery sleep in the mouse brain. Neuroscience 120:1115-1124.

Terao A, Steininger TL, Morairty SR, Kilduff TS (2004) Age-related changes in histamine receptor mRNA levels in the mouse brain. Neurosci Lett 355:81-84.

Terao A, Wisor JP, Peyron C, Apte-Deshpande A, Wurts SW, Edgar DM, Kilduff TS (2006) Gene expression in the rat brain during sleep deprivation and recovery sleep: an Affymetrix GeneChip(R) study. Neuroscience 137:593-605.

Thompson CL, Selby CP, Partch CL, Plante DT, Thresher RJ, Araujo F, Sancar A (2004) Further evidence for the role of cryptochromes in retinohypothalamic photoreception/phototransduction. Brain Res Mol Brain Res 122:158-166.

Travnickova-Bendova Z, Cermakian N, Reppert SM, Sassone-Corsi P (2002) Bimodal regulation of mPeriod promoters by CREB-dependent signaling and CLOCK/BMAL1 activity. Proc Natl Acad Sci U S A 99:7728-7733.

Ueda HR, Hayashi S, Chen W, Sano M, Machida M, Shigeyoshi Y, Iino M, Hashimoto S (2005) System-level identification of transcriptional circuits underlying mammalian circadian clocks. Nat Genet 37:187-192.

van der Horst GT, Muijtjens M, Kobayashi K, Takano R, Kanno S, Takao M, de Wit J, Verkerk A, Eker AP, van Leenen D, Buijs R, Bootsma D, Hoeijmakers JH, Yasui A (1999) Mammalian Cryl and Cry2 are essential for maintenance of circadian rhythms. Nature 398:627-630.

Vitaterna MH, Selby CP, Todo T, Niwa H, Thompson C, Fruechte EM, Hitomi K, Thresher RJ, Ishikawa T, Miyazaki J, Takahashi JS, Sancar A (1999) Differential regulation of mammalian period genes and circadian rhythmicity by cryptochromes 1 and 2. Proc Natl Acad Sci U S A 96:12114-12119.

Wisor JP, Kilduff TS (2005) Molecular genetic advances in sleep research and their relevance to sleep medicine. Sleep 28:357-367.

Wisor JP, O’Hara BF, Terao A, Selby CP, Kilduff TS, Sancar A, Edgar DM, Franken P (2002) A role for cryptochromes in sleep regulation. BMC Neurosci 3:20.

Yagita K, Tamanini F, van Der Horst GT, Okamura H (2001) Molecular mechanisms of the biological clock in cultured fibroblasts. Science 292:278-281.

Zheng B, Albrecht U, Kaasik K, Sage M, Lu W, Vaishnav S, Li Q, Sun ZS, Eichele G, Bradley A, Lee CC (2001) Nonredundant roles of the mPer 1 and mPer2 genes in the mammalian circadian clock. Cell 105:683-694. 